\title{
Mitochondrial DNA and allozyme patterns of Hediste diversicolor (Polychaeta: Nereididae): the importance of small scale genetic structuring
}

\author{
Massimiliano Virgilio $^{1, *}$, Thierry Backeljau ${ }^{2,3}$, Marco Abbiati ${ }^{1}$ \\ ${ }^{1}$ Centro Interdipartimentale di Ricerca per le Scienze Ambientali and Dipartimento di Biologia Evoluzionistica \\ e Sperimentale, University of Bologna, Via S. Alberto 163, 48100 Ravenna, Italy \\ ${ }^{2}$ Royal Belgian Institute of Natural Sciences, Vautierstraat 29, 1000 Brussels, Belgium \\ ${ }^{3}$ Evolutionary Biology Group, University of Antwerp, Groenenborgerlaan 171, 2020 Antwerp, Belgium
}

\begin{abstract}
A hierarchical sampling design was used to describe scales of genetic structuring of Hediste diversicolor (Polychaeta: Nereididae) along the North Adriatic coast of Italy and investigate possible relationships with patterns of heavy metal contamination. Analyses of a fragment of the mitochondrial cytochrome oxidase 1 (COI) gene yielded 10 different haplotypes showing that the genetic structuring at this locus is more complex than previously hypothesised. Both COI and allozyme data suggest that most of the total genetic variance is due to genetic differentiation among (1) sites within estuaries and (2) individuals within sites. These results suggest that within estuaries $H$. diversicolor does not form contiguous panmictic populations, but rather is structured in fragmented populations isolated at small spatial scales. Sediment concentrations of $\mathrm{Zn}, \mathrm{Cu}$ and $\mathrm{Ni}$ in sediments were above effects range-low (ERL) guideline values at several of the investigated sites. Yet, we did not observe any relationship between heavy metal concentrations of metals and either the estimators of genetic diversity in $H$. diversicolor or the distribution of Aldolase genotypes expected from previous toxicity tests. These results suggest that, within North Adriatic estuaries, populations of $H$. diversicolor are structured by chaotic genetic patchiness and that stochastic processes (e.g. genetic drift or sweepstake recruitment) have a major role in promoting small scale genetic structuring.
\end{abstract}

KEY WORDS: Hediste diversicolor - mtDNA - Allozymes - Genetic structuring - Heavy metals · Estuarine environments

\section{INTRODUCTION}

Anthropogenic stressors (e.g. heavy metals, hydrocarbons or radionuclides) are known to affect the genetic diversity and structuring of populations by various, often interacting processes such as adaptation, through natural selection, or genetic drift after size reductions of exposed populations (Belfiore \& Anderson 2001). Processes promoting changes in genotype or allele frequencies also occur under natural, nonstressed conditions (Avise 2000). Hence, the possible genetic effects of anthropogenic stressors are generally difficult to disentangle from the effects caused by microevolutionary processes that are not caused by these stressors (De Wolf et al. 2004). Thus, the extent of anthropogenically induced changes in the genetic patterns of populations should be evaluated through different, complementary approaches involving both laboratory experiments under controlled conditions and field surveys (Belfiore \& Anderson 2001). Reconciling laboratory results with field observations requires a comprehensive description of the genetic and phylogeographic structuring of the target species population so that the effects of natural and anthropogenic stress can be distinguished and their relative importance evaluated (Staton et al. 2001). 
Laboratory experiments have shown that heavy metal contamination may have substantial population genetic effects (reviewed in Belfiore \& Anderson 2001). Yet, convincing examples of genetic changes provoked by heavy metals in field conditions are far less prevalent, mainly due to the difficulty of choosing truly comparable polluted and reference sites that unequivocally allow the patterns of genetic variation to be related to levels of contamination (Bickham et al. 2000, Staton et al. 2001, Belfiore \& Anderson 2001). Moreover, environmental concentrations and bioavailabilities of metals depend on several processes such as chemical speciation in sediments or levels of metal uptake and accumulation in organisms (Bryan \& Langston 1992). Assessing the genetic impacts of heavy metal contamination under field conditions thus depends heavily on the correct estimation of levels of contaminants in the environment and in the tissues of target organisms.

Hediste diversicolor (O. F. Müller) is a widespread estuarine polychaete with a short dispersing larval stage (Scaps 2002). This species plays a major role in estuarine food webs (Desroy et al. 1998) and biogeochemical cycles (Hansen \& Kristensen 1998) of European estuaries, and has been proposed as a sentinel species in the biomonitoring of anthropogenic stressors (Grant et al. 1989, Ozoh 1994, Diez et al. 2000, Virgilio \& Abbiati 2004a). Heavy metal stress promotes genotypic shifts in the allozyme patterns of laboratory populations of $H$. diversicolor (Virgilio \& Abbiati 2004a). Previous experiments (Virgilio et al. 2005) revealed that relationships between laboratory exposure to copper and genotype-tolerance responses at the enzyme locus Aldolase (ALD) were consistent both in space (i.e. among samples of $H$. diversicolor collected from sites thousands of kilometres apart) and in time (i.e. among different laboratory experiments). In particular, specimens with genotype ALD ${ }^{102 / 102}$ showed shorter survival times under copper exposure. These results suggested that, in field populations of $H$. diversicolor, frequencies of genotype ALD ${ }^{102 / 102}$ may be correlated to levels of copper contamination and that differences in genotype frequencies at ALD may be used as an indicator of copper stress (Virgilio et al. 2005).

Patterns of genetic structuring of field populations of Hediste diversicolor have been described by using allozyme (reviewed in Scaps 2002) and molecular markers (Breton et al. 2003). Previous studies analysing the allozyme patterns of $H$. diversicolor along the Italian and North European coasts showed a general tendency to genetic structuring among populations from different estuaries (Abbiati \& Maltagliati 1996, Rohner et al. 1997, Virgilio \& Abbiati 2004b). These results suggest that at spatial scales from tens to thousands of kilometres the limited dispersal capabilities of $H$. di- versicolor may promote genetic fragmentation among estuarine environments (Bilton et al. 2002). Analyses of allozyme patterns of populations of $H$. diversicolor from the North Adriatic coast of Italy (Virgilio \& Abbiati 2004b) show that levels of genetic divergence among populations are not primarily related to the coastal distances among estuaries as expected under the isolation by distance model (Avise 2000). Information on genetic structuring at smaller spatial scales (i.e. within estuaries) is scarce but preliminary results show that allozyme patterns of samples of $H$. diversicolor significantly differ within a North Adriatic estuary (Pialassa lagoon), possibly being affected by levels of heavy metal contamination (Virgilio et al. 2003). These results suggest that genetic divergence among populations colonising the same estuary may be an important and possibly overlooked source of genetic variability. It still remains an open question to what extent natural or anthropogenic stressors (e.g. salinity, heavy metals) and microevolutionary processes (e.g. genetic drift) may, alone or combined, affect the genetic patterns of $H$. diversicolor in the field (Virgilio et al. 2005). A comprehensive analysis of relationships among scales of genetic structuring of $H$. diversicolor, patterns of heavy metal contamination and distribution of ALD genotypes expected from laboratory predictions may thus provide valuable information about microevolutionary and ecological processes affecting the genetic patterns of this species.

This study analysed the genetic structuring of Hediste diversicolor at allozyme and mitochondrial DNA loci and investigated possible relationships between genetic patterns of the species and heavy metal contamination of estuaries along the North Adriatic coast of Italy. A hierarchical sampling design was implemented to (1) describe the genetic structuring of $H$. diversicolor within and among estuaries, (2) verify if the genetic patterns of field populations of $H$. diversicolor are correlated with levels of heavy metal contamination and (3) test if previous laboratory results (Virgilio et al. 2005) may be used to predict the genetic patterns of $H$. diversicolor at sites with different levels of copper contamination.

\section{MATERIALS AND METHODS}

Sampling design. Five estuaries (Grado, Venezia, Goro, Comacchio, Pialassa) were chosen along the North Adriatic coast of Italy (Fig. 1). Shoreline distances between any two estuaries ranged from $20 \mathrm{~km}$ (between Goro and Comacchio) to about $230 \mathrm{~km}$ (between Grado and Pialassa). Within each estuary, 3 intertidal sites, located at distances from 2 to $15 \mathrm{~km}$, were surveyed for both patterns of genetic variation in 


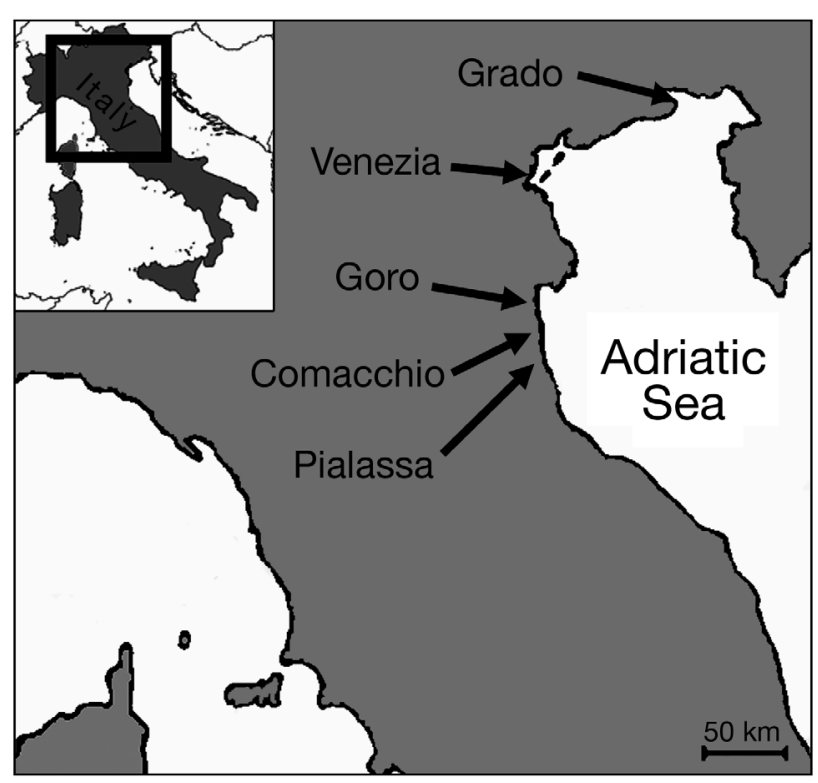

Fig. 1. Hediste diversicolor. Map of the North Adriatic coast of Italy showing estuaries sampled (Grado, Venezia, Goro, Comacchio, Pialassa). Each estuary was sampled at 3 replicate sites

Hediste diversicolor and levels of heavy metal contamination. At each site, specimens of $H$. diversicolor were collected by uniformly sampling an intertidal area of approximately $10 \times 1 \mathrm{~m}$. This procedure reduced possible biases due to clustered sampling of closely related individuals. Concentrations of $\mathrm{Cd}, \mathrm{Cu}, \mathrm{Ni}, \mathrm{Pb}$ and $\mathrm{Zn}$ were quantified in both samples of sediments and tissues of $H$. diversicolor. Samples of sediments were obtained by mixing the contents of 3 cores (diameter $5 \mathrm{~cm}$, depth $20 \mathrm{~cm}$ ) randomly collected at each site. Similarly, samples of tissues were obtained by pooling 10 specimens of $H$. diversicolor from each site. Pooling procedures reduced biases due to small scale variability in heavy metal concentrations previously observed within sites (Virgilio et al. 2003).

Analyses of a mitochondrial cytochrome oxidase 1 (COI) gene fragment. The DNA was extracted from each specimen following a standard CTAB-extraction procedure (Winnepenninckx et al. 1993) and suspended in $50 \mu$ l of double distilled $\mathrm{H}_{2} \mathrm{O}$. The PCR primers described by Breton et al. (2003) were used to amplify a mitochondrial COI fragment. A PCR was performed in $20 \mu \mathrm{l}$ containing $5 \mathrm{mM} \mathrm{MgCl}_{2}, 2 \mu \mathrm{M}$ of each dNTP, $0.1 \mu \mathrm{M}$ of each primer, 0.025 units of Taq Polymerase (Promega), $2 \mu$ of 10X PCR buffer (Promega), and $2 \mu \mathrm{l}$ of DNA extract. Samples were subjected to the following temperature profile: initial denaturation at $94^{\circ} \mathrm{C}$ for $4 \mathrm{~min}$, then 9 cycles of $94^{\circ} \mathrm{C}$ denaturing for $45 \mathrm{~s}, 55^{\circ} \mathrm{C}$ annealing for $1 \mathrm{~min}$, and $72^{\circ} \mathrm{C}$ extension for $1 \mathrm{~min}$, followed by 26 cycles where denaturing was performed at $93^{\circ} \mathrm{C}$ for $30 \mathrm{~s}$, annealing at $45^{\circ} \mathrm{C}$ for $45 \mathrm{~s}$ and extension at $72^{\circ} \mathrm{C}$ for $45 \mathrm{~s}$. Finally, samples were subjected to $72^{\circ} \mathrm{C}$ for $5 \mathrm{~min}$. Single strand conformation polymorphisms (SSCP) were analysed by adding $15 \mu \mathrm{l}$ of denaturing buffer (95\% formamide, $20 \mu \mathrm{l}$ of EDTA $0.5 \mathrm{M}, 20 \mu \mathrm{l}$ of $\mathrm{NaOH} 1 \mathrm{M}, 0.02 \%$ bromophenol blue, $0.02 \%$ xylene cyanol) to $4 \mu$ l of $\mathrm{PCR}$ reaction mixture. After denaturing at $94^{\circ} \mathrm{C}$ for $4 \mathrm{~min}$ and quickly chilling on ice, a $13.5 \mu \mathrm{l}$ aliquot was subjected to electrophoresis on a $1 \times$ TAE $10 \%$ nondenaturing polyacrylamide gel at $30 \mathrm{~V}$ for $2.5 \mathrm{~h}$ at $4^{\circ} \mathrm{C}$. The SSCP bands were visualized by silver staining. In order to verify that identical SSCP bands corresponded to DNA fragments with the same nucleotide composition, at least 3 representatives of each variant SSCP haplotype were sequenced (except for some rare haplotypes). The PCR products were purified by using the ExoSAP Kit (Amersham Biosciences). Both strands of purified PCR products were cycle-sequenced using the same primers used for amplification (Breton et al. 2003) and the ABIPrism BigDye Terminator Cycle Sequencing kit (Applied Biosystems). Sequences were resolved on an ABI310 Genetic Analyser (Applied Biosystems). Since no differences were found in the nucleotide composition of representatives of each variant SSCP haplotype, we associated each specimen to a $341 \mathrm{bp}$ DNA sequence. Sequences corresponding to each haplotype were deposited in GenBank under accession numbers from DQ139785 to DQ139794.

Allozyme electrophoresis. The same specimens used for mtDNA analyses were analysed at 5 allozyme markers (Aldolase: ALD, E.C. 4.1.2.13; Fumarate hydratase: FH, E.C. 4.2.1.2; Lactate dehydrogenase: LDH, E.C. 1.1.1.27; Phosphoglucose isomerase: PGI; E.C. 5.3.1.9; Sorbitol dehydrogenase: SDH, E.C. 1.1.1.14) that in previous field surveys (Virgilio et al. 2003) and laboratory experiments (Virgilio \& Abbiati 2004a, Virgilio et al. 2005) showed possible relationships with levels of heavy metal contamination. Cellulose acetate gel electrophoresis (CAGE) and staining were performed as described by Virgilio \& Abbiati (2004b). For each specimen, about $100 \mathrm{mg}$ of tissue from the central segments were homogenised in $100 \mu \mathrm{l}$ of extracting buffer (Tris-HCl $0.05 \mathrm{M} \mathrm{pH} \mathrm{8,} \mathrm{Triton-X-}$ 100 1:1000). A Tris-EDTA-maleic acid (pH 7.8) electrode buffer (Schneppenheim \& MacDonald 1984) was used in 1:1 and 1:2 dilutions. For each locus the most common allele in the population from the Pialassa estuary was designated as allele 100, while other alleles were numbered according to their relative mobilities.

Levels of heavy metal contamination. Concentrations of $\mathrm{Cu}, \mathrm{Ni} \mathrm{Zn}$ and $\mathrm{Cd}$ were quantified by means of atomic absorption spectrometry (AAS) and concentrations of $\mathrm{Pb}$ by inductively coupled plasma mass spec- 
trometry (ICP-MS). Before chemical analyses specimens of Hediste diversicolor were kept for $72 \mathrm{~h}$ in glass dishes containing brackish water from the sampling sites to void the gut of sediment. Analyses were performed in triplicate on samples of sediments dried overnight at $70^{\circ} \mathrm{C}$ and on freeze-dried samples of $H$. diversicolor. Reagent blanks and certified reference materials, MESS-3 (marine sediment) and TORT-2 (lobster hepatopancreas), were analysed concurrently with sediment and tissue samples to validate the method used (precision 10\% and accuracy 92\%, as recovery with respect to the certified value). Samples were mineralised in a microwave system using $\mathrm{HNO}_{3} / \mathrm{HCl} / \mathrm{HF}$ for sediments and $\mathrm{HNO}_{3}$ for $H$. diversicolor tissues. Concentrations were expressed as ppm dry weight.

Data analyses. The DNA sequences were edited and aligned using ClustalX (Thompson et al. 1997). Average base frequencies, pairwise sequence divergence, haplotype diversities ( $h$ ) and nucleotide diversities $(\pi)$ were calculated using Mega 3.0 (Kumar et al. 2001) and Arlequin 2.0 (Schneider et al. 2000). A haplotype network was estimated by finding haplotype connections with probabilities above the 0.95 statistical limit, as implemented by the program TCS 1.13 (Clement et al. 2000). The mean number of alleles per allozyme locus, the observed heterozygosity $\left(H_{\text {obs }}\right)$ and the unbiased expected heterozygosity $\left(H_{\text {exp }}\right.$ Nei 1978) were calculated using GENETIX (Belkhir et al. 1996). Genotype frequencies at allozyme loci were tested for deviations from Hardy-Weinberg equilibrium (HWE) using an exact probability test. To correct for Type I error, multiple tests were adjusted using the False Discovery Rate procedure (Benjamini \& Hochberg 1995). Non-metric multidimensional scaling (MDS) was performed using PRIMER v5 (Clarke \& Gorley 2001) and used to represent the genetic patterns of Hediste diversicolor in bidimensional space. The MDS plots were based on (1) Kimura 2-parameter (K2P) corrected average pairwise differences between populations (Schneider et al. 2000) calculated from SSCP analyses and sequencing of the mitochondrial COI gene fragment, and (2) Cavalli-Sforza \& Edward's (1967) genetic distances calculated over all allozyme loci (Belkhir et al. 1996). Hierarchical analysis of molecular variance (AMOVA) was used to partition the observed genetic variation into (1) amongestuary contribution, (2) among-sites (within-estuary) contribution, and (3) among-individuals (within-site) contribution. The AMOVAs were run separately on mtDNA haplotype frequencies and allozyme frequencies. Measures of genetic variance were tested for significance by using nonparametric permutational tests as implemented by Arlequin 2.000 (Schneider et al. 2000). Permutational tests were based on $\Phi$ statistics
(Excoffier et al. 1992), and on conventional F statistics (Weir \& Cockerham 1984) for mtDNA and allozyme data, respectively.

In order to verify if levels of contamination of sediments may promote biological effects on populations of Hediste diversicolor, we compared concentrations of heavy metals at each site with effects range-low (ERL) and effects range-median (ERM) guideline values provided by Long et al. (1995, 1998). Concentrations below ERL are rarely associated with adverse effects, while the probabilities of biological effects increase between ERL and ERM and above ERM (Long et al. 1995, 1998). We used guideline values for $\mathrm{Cd}, \mathrm{Cu}, \mathrm{Ni}$, $\mathrm{Pb}$ and $\mathrm{Zn}$ (Long et al. 1995, 1998) to calculate the number of sites in which concentrations of metals were (1) below ERL, (2) between ERL and ERM and (3) above ERM. Spearman rank correlation coefficients were used to test correlations between concentrations of $\mathrm{Cd}, \mathrm{Cu}, \mathrm{Ni}, \mathrm{Pb}$ and $\mathrm{Zn}$ (either in sediments or in tissues) and estimators of genetic diversity $\left(h, \pi, H_{\text {obs }}\right)$. In order to verify whether ALD ${ }^{102 / 102}$ genotype frequency may be used as a possible indicator of $\mathrm{Cu}$ stress in field populations of $H$. diversicolor (Virgilio et al. 2005), correlations between $\mathrm{ALD}^{102 / 102}$ frequencies and levels of $\mathrm{Cu}$ contamination (either in sediments or in tissues) were also tested.

\section{RESULTS}

A total of 10 variant SSCP haplotypes were observed. Sequencing of SSCP haplotypes showed that the $341 \mathrm{bp}$ COI fragments were characterised by 105 variable positions, and an average of 20.2 transitions (SE = 2.6) and 20.6 transversions $(\mathrm{SE}=3.0)$ for each haplotype pair. Average base frequencies of haplotypes were A: $26.7 \%(\mathrm{SE}=0.6 \%) ; \mathrm{C}: 24.5 \%$ (SE = $0.4 \%) ; \mathrm{G}: 17.2 \%(\mathrm{SE}=0.1 \%) ;$ and $\mathrm{T}: 31.6 \%(\mathrm{SE}=$ $0.4 \%$ ). In the 15 samples of Hediste diversicolor analysed, haplotype I was the most common with frequencies ranging from 0.47 to 1.00 while the other 9 haplotypes occurred at lower frequencies ranging from 0.00 to 0.33 (Table 1). Haplotype diversity and nucleotide diversity varied from $h=0.00$ to $h=0.71$ and from $\pi=0.001$ ( $\mathrm{SE}=0.001$ ) to $\pi=0.107$ ( $\mathrm{SE}=0.053$ ) (Table 1). Levels of polymorphism at the COI fragment were not primarily affected by sample size as several samples with higher numbers of specimens (e.g. Grado $1, \mathrm{n}=43$; Comacchio $1, \mathrm{n}=28$ ) were monomorphic while other samples with a low number of specimens (e.g. Venezia 2 and Venezia 3, n = 9) were polymorphic. Accordingly, haplotype diversity was not correlated with the mean number of individuals sampled (Spearman $r=-0.071, \mathrm{p}=0.80)$. The haplotype network (Fig. 2) showed up to 7 mutational steps between 
Table 1. Hediste diversicolor. Haplotype frequencies, haplotype diversity $(h)$ and nucleotide diversity $(\pi \pm$ SE) at 3 replicate sites within 5 estuaries along the North Adriatic coast of Italy $(n=$ number of specimens analysed)

\begin{tabular}{|c|c|c|c|c|c|c|c|c|c|c|c|c|c|c|}
\hline \multirow{2}{*}{ Estuary } & \multirow{2}{*}{ Site } & \multirow{2}{*}{$\mathrm{n}$} & \multicolumn{10}{|c|}{ - Haplotype frequencies - } & \multirow{2}{*}{$h$} & \multirow{2}{*}{$\pi$} \\
\hline & & & I & II & III & IV & V & VI & VII & VIII & IX & $\mathrm{X}$ & & \\
\hline \multirow[t]{3}{*}{ Grado } & 1 & 43 & 1.00 & & & & & & & & & & 0.00 & - \\
\hline & 2 & 23 & 0.70 & 0.04 & 0.04 & & 0.04 & & & 0.13 & & 0.04 & 0.51 & $0.069 \pm 0.035$ \\
\hline & 3 & 30 & 0.47 & & & 0.13 & 0.17 & & & & & 0.23 & 0.71 & $0.107 \pm 0.053$ \\
\hline \multirow[t]{3}{*}{ Venezia } & 1 & 12 & 1.00 & & & & & & & & & & 0.00 & - \\
\hline & 2 & 9 & 0.89 & & & & & & & 0.11 & & & 0.22 & $0.001 \pm 0.001$ \\
\hline & 3 & 9 & 0.78 & & & 0.11 & & & & 0.11 & & & 0.42 & $0.002 \pm 0.002$ \\
\hline \multirow[t]{3}{*}{ Goro } & 1 & 29 & 0.93 & & & & & 0.03 & & & & 0.03 & 0.14 & $0.020 \pm 0.010$ \\
\hline & 2 & 31 & 0.94 & & & & 0.03 & & & & 0.03 & & 0.13 & $0.001 \pm 0.001$ \\
\hline & 3 & 28 & 1.00 & & & & & & & & & & 0.00 & - \\
\hline \multirow[t]{3}{*}{ Comacchio } & 1 & 28 & 1.00 & & & & & & & & & & 0.00 & - \\
\hline & 2 & 27 & 1.00 & & & & & & & & & & 0.00 & - \\
\hline & 3 & 24 & 1.00 & & & & & & & & & & 0.00 & - \\
\hline \multirow[t]{3}{*}{ Pialassa } & 1 & 20 & 0.90 & & & & & & & 0.10 & & & 0.19 & $0.001 \pm 0.001$ \\
\hline & 2 & 28 & 0.79 & & & & 0.11 & & 0.04 & & & 0.07 & 0.38 & $0.041 \pm 0.021$ \\
\hline & 3 & 30 & 0.53 & & & & & & & 0.33 & & 0.13 & 0.61 & $0.069 \pm 0.035$ \\
\hline
\end{tabular}

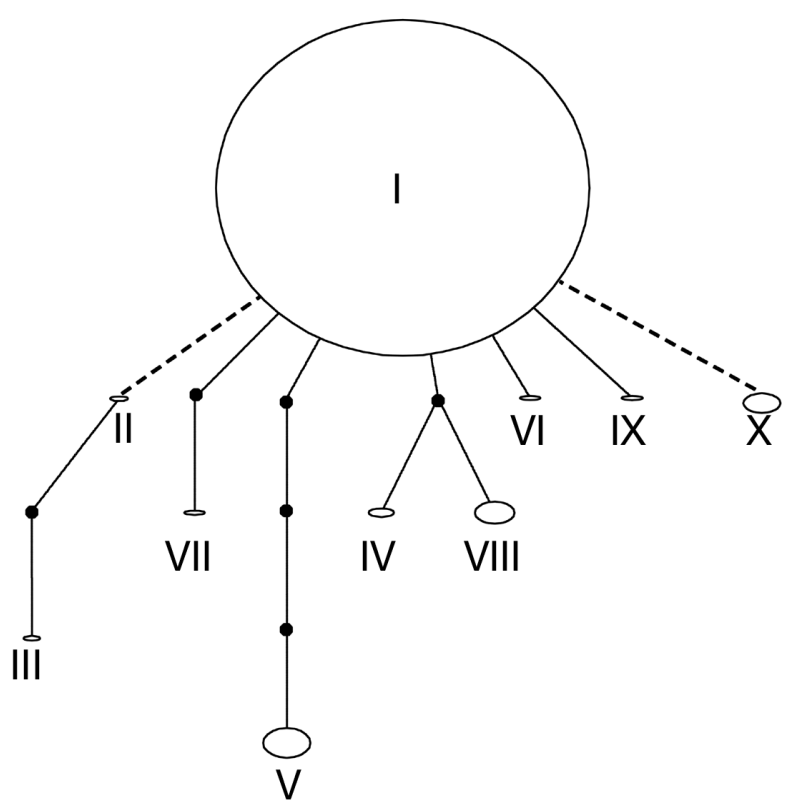

Fig. 2. Hediste diversicolor. Haplotype network for the mitochondrial DNA sequences (COI). Each haplotype (I to X) is represented by a circle, the surface area of which is proportional to the number of haplotypes observed. Solid dots indicate intermediate haplotypes that are not present in the sample. Ambiguities (haplotypes that have alternative most parsimonious connections to the rest of the network) are represented by dashed lines

haplotypes. The K2P corrected average pairwise differences between populations ranged from 0.00 to 4.75 (between Grado 3 and Comacchio 1, 2 and 3). The MDS based on K2P corrected average pairwise differences between populations (Fig. 3a) provided a good fit to the observed data (stress $=0.05$ ) and showed a

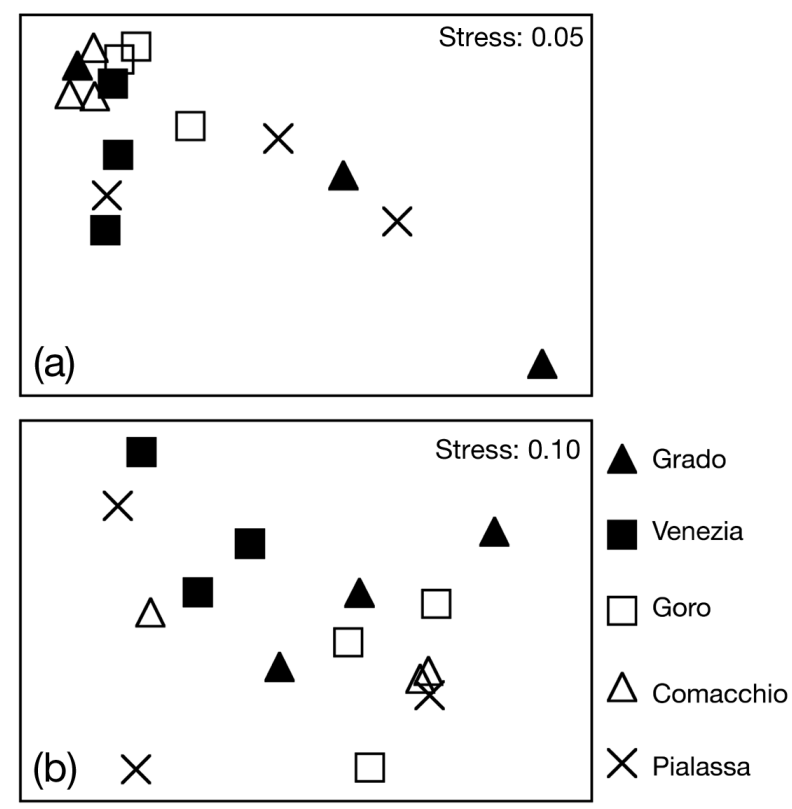

Fig. 3. Hediste diversicolor. Multidimensional scaling (MDS) plots describing the genetic structuring of populations sampled in 5 estuaries (Grado, Venezia, Goro, Comacchio, Pialassa) sampled at 3 replicate sites. The MDSs were based on (a) Kimura 2-parameter corrected average pairwise differences between populations obtained by SSCP analyses and sequencing of the mitochondrial COI gene, and (b) CavalliSforza \& Edward's (1967) genetic distances calculated over all allozyme loci

complex pattern of genetic structuring that did not reflect the relative geographic location of sites or estuaries. The AMOVA based on the mtDNA haplotype frequencies showed that the largest part of molecular variance was explained by individual variation within 
sites $($ percentage of variation $=81.57 \%, p<0.001$ ). A highly significant contribution to the overall genetic variation was also attributed to differences among sites within estuaries (percentage of variation $=15.37 \%$, p < 0.001), while the variance contribution by differences among estuaries was not significant (percentage of variation $=3.06 \%$ ) .

The allozyme data are provided in Table 2. The mean number of alleles per locus ranged from 1.4 to $3.0, H_{\mathrm{obs}}$ ranged from $0.048(\mathrm{SE}=0.034)$ to $0.192(\mathrm{SE}=$ 0.055 ), and $H_{\text {exp }}$ ranged from 0.054 ( $\mathrm{SE}=0.040$ ) to 0.250 ( $\mathrm{SE}=0.052$ ). After the False Discovery Rate procedure, significant HWE deviations were observed in 6 out of 50 tests. Cavalli-Sforza \& Edward's (1967)

Table 2. Hediste diversicolor. Measures of genetic variability at 5 allozyme loci (ALD, FH, LDH, PGI, SDH). Samples were collected at 5 estuaries along the North Adriatic coast of Italy. Each estuary was sampled at 3 replicate sites (n: sample size, mna: mean number of alleles). Mean $H_{\mathrm{obs}}$ is the mean observed heterozygosity and mean $H_{\text {exp }}$ is the mean expected unbiased heterozygosity (Nei 1978); standard errors are in parentheses

\begin{tabular}{|lccccc|}
\hline Estuary & Site & $\mathrm{n}$ & mna & Mean $H_{\text {obs }}$ & Mean $H_{\text {exp }}$ \\
\hline Grado & 1 & $33.6(1.2)$ & 1.8 & $0.090(0.049)$ & $0.155(0.063)$ \\
& 2 & $32.4(1.2)$ & 2.0 & $0.068(0.049)$ & $0.119(0.073)$ \\
Venezia & 3 & $35.0(0.0)$ & 2.0 & $0.103(0.062)$ & $0.119(0.079)$ \\
& 1 & $34.0(1.0)$ & 2.8 & $0.181(0.050)$ & $0.250(0.052)$ \\
& 2 & $34.0(0.4)$ & 2.0 & $0.131(0.040)$ & $0.202(0.056)$ \\
Goro & 3 & $33.4(1.6)$ & 2.6 & $0.164(0.053)$ & $0.165(0.053)$ \\
& 1 & $34.0(1.0)$ & 1.8 & $0.059(0.037)$ & $0.084(0.048)$ \\
Comacchio & 2 & $33.6(1.0)$ & 2.4 & $0.086(0.023)$ & $0.103(0.029)$ \\
& 3 & $34.0(1.0)$ & 1.8 & $0.052(0.024)$ & $0.069(0.041)$ \\
Pialassa & 2 & $38.2(1.8)$ & 2.4 & $0.178(0.052)$ & $0.193(0.069)$ \\
& 3 & $33.8(1.0)$ & 1.6 & $0.057(0.044)$ & $0.067(0.053)$ \\
& 1 & $33.4(1.6)$ & 2.6 & $0.048(0.034)$ & $0.054(0.040)$ \\
& 2 & $34.6(0.4)$ & 3.0 & $0.157(0.047)$ & $0.243(0.084)$ \\
& 3 & $35.0(0.0)$ & 1.4 & $0.086(0.072)$ & $0.092(0.078)$ \\
\hline
\end{tabular}

Table 3. Hediste diversicolor. AMOVA on mtDNA haplotype frequencies and allozyme frequencies. Samples were collected at 3 replicate sites within 5 estuaries along the north Adriatic coast of Italy. df: degrees of freedom; SS: sum of squares; var. comp.: variance components; \% var: percentage of variation; ${ }^{* * *}: \mathrm{p}<0.001 ;$ ns: not significant

\begin{tabular}{|c|c|c|c|c|c|c|c|c|}
\hline \multirow{2}{*}{$\begin{array}{l}\text { Source of } \\
\text { variation }\end{array}$} & \multicolumn{4}{|c|}{ Haplotype frequencies } & \multicolumn{4}{|c|}{ Allozyme frequencies } \\
\hline & df & SS & $\begin{array}{l}\text { var. } \\
\text { comp. }\end{array}$ & $\begin{array}{c}\% \\
\text { var. }\end{array}$ & $\mathrm{df}$ & SS & $\begin{array}{l}\text { var. } \\
\text { comp. }\end{array}$ & $\begin{array}{c}\% \\
\text { var. }\end{array}$ \\
\hline Among estuaries & 4 & 3.57 & 0.004 & $3.06^{\mathrm{ns}}$ & 4 & 4.56 & 0.002 & $1.10^{\mathrm{ns}}$ \\
\hline $\begin{array}{l}\text { Among sites } \\
\text { within estuaries }\end{array}$ & 10 & 5.97 & 0.020 & $15.37^{* * *}$ & 10 & 5.88 & 0.005 & $2.16^{* * *}$ \\
\hline Within sites & 356 & 37.95 & 0.107 & $81.57^{* * *}$ & 1055 & 239.09 & 0.227 & $96.73^{* * *}$ \\
\hline Total & 370 & 47.49 & 0.131 & & 1069 & 249.53 & 0.234 & \\
\hline
\end{tabular}

genetic distances ranged from $D c=0.003$ (between Comacchio 1 and Comacchio 3) to $D C=0.072$ Venezia 1 and Pialassa 3). The MDS of pattern of genetic structuring, unrelated to the relo tive geographic location of sites or estuaries (Fig. 3b). The AMOVA (Table 3) based on allozyme frequencies showed that the largest part of the overall molecular variance was attributable to individual variation within sites (percentage of variation $=96.73 \%, p<$ .001). A highly significant contribution to genetic iation was also due to differences among sites within estuaries (percentage of variation $=2.16 \%, \mathrm{p}<$ 0.001 ), while the variance contribution by differences among estuaries was not significant (percentage of variation $=1.10 \%$ ).

Heavy metal concentrations in sediments and tissue of Hediste diversicolor varied both among and within estuaries (Fig. 4). Sediment concentrations of $\mathrm{Cd}$ ranged from 0.093 to $0.94 \mathrm{ppm}$ and from 0.019 to $1.02 \mathrm{ppm}$ in tissues of $H$. diversicolor. $\mathrm{Cu}$ in sediments ranged from $5.77 \mathrm{ppm}$ to $49.97 \mathrm{ppm}$, and in tissues from $12.22 \mathrm{ppm}$ to $47.90 \mathrm{ppm}$. Ni in sediments ranged from 12.57 to $55.93 \mathrm{ppm}$ and in tissues of $H$. diversicolor from 0.032 to $11.14 \mathrm{ppm}$. Concentrations of $\mathrm{Pb}$ ranged from 1.05 to $20.44 \mathrm{ppm}$ in sediments and from 0.21 to $2.32 \mathrm{ppm}$ in tissues of $H$. diversicolor. Concentrations of $\mathrm{Zn}$ ranged from 33.87 to $277.67 \mathrm{ppm}$ in sediments and from 70.10 to $167.83 \mathrm{ppm}$ in tissues of $H$. diversicolor. Concentrations of $\mathrm{Ni}$ in sediments were above ERM at 3 out of 15 sites. Sediment concentrations of $\mathrm{Cu}, \mathrm{Ni}$ and $\mathrm{Zn}$ were between ERL and ERM at 2, 9 and 1 sites, respectively, while those of $\mathrm{Cd}$ and $\mathrm{Pb}$ were below ERL values at all the investigated sites (Fig. 4). As shown in Table 4, the different estimates of genetic diversity were not significantly correlated with concentrations of heavy metals either in sediments or in tissues. Furthermore, ALD ${ }^{102 / 102}$ frequencies were not correlated with concentrations of $\mathrm{Cu}$ either in sediments (Spearman $r=0.047$, ns) or in tissues of $H$. diversicolor (Spearman $r=0.082$, ns). 

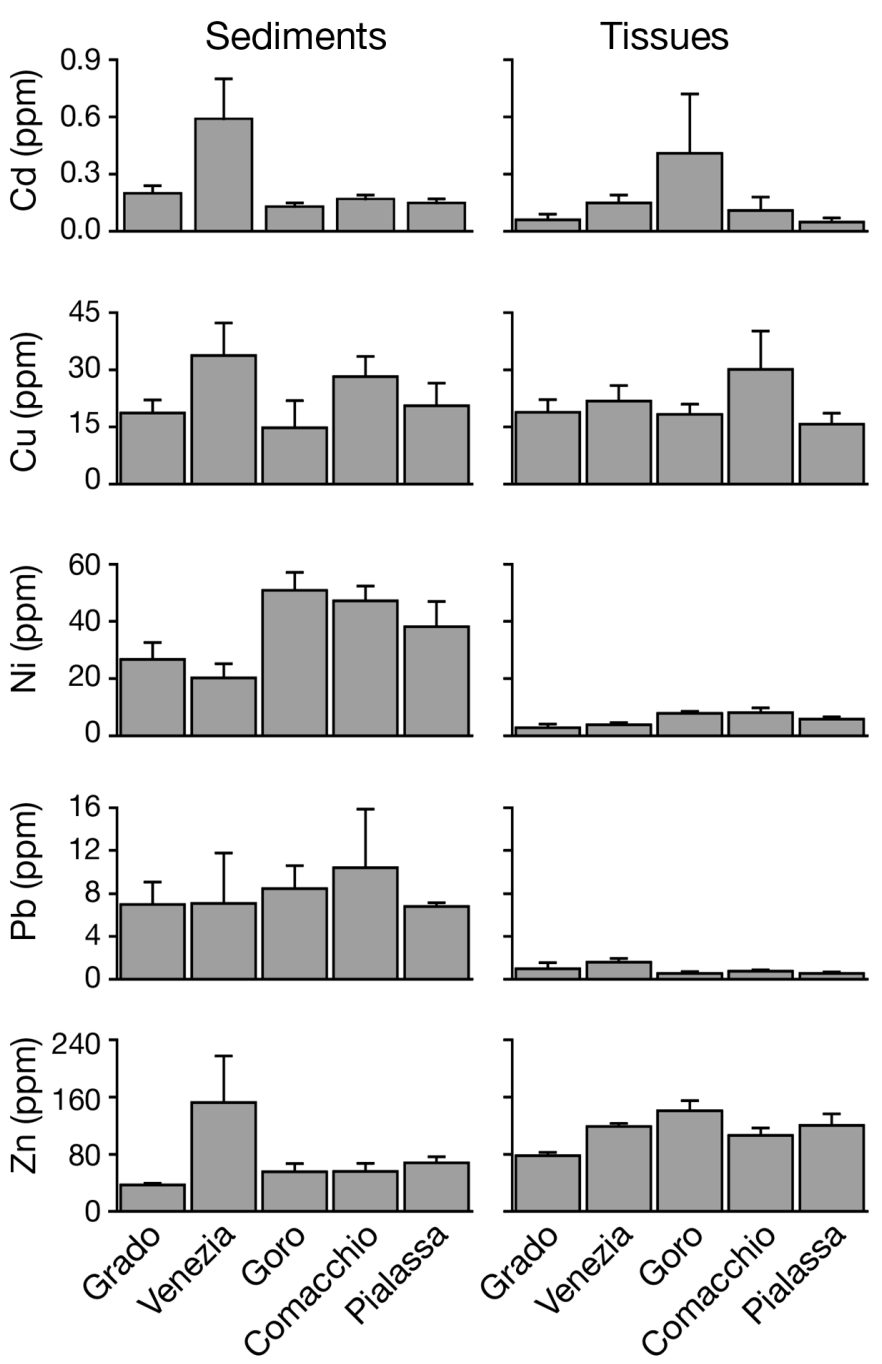

Fig. 4. Average concentrations of $\mathrm{Cd}, \mathrm{Cu}, \mathrm{Ni}, \mathrm{Pb}$ and $\mathrm{Zn}$ (+ SE, $\mathrm{n}=3$ ) in estuarine sediments and Hediste diversicolor tissues

\section{DISCUSSION}

Breton et al. (2003), analysing the same COI fragment considered in this study, did not observe any variation among 3 populations of Hediste diversicolor from the Mediterranean coast of France (Marseille, $\mathrm{n}=$ 11) and from the Atlantic coasts of France (Roscoff, $n=$ 12) and Canada (Chaleur Bay, $\mathrm{n}=10$ ). This study analysed a larger number of samples and specimens and showed that the COI fragment comprises at least 10 different haplotypes. Even if the genetic structuring at the COI locus in $H$. diversicolor appears more complex than previously hypothesised, most of the haplotypes occur at low frequencies and several populations are monomorphic. Regardless of the low levels of genetic variability detected at the COI fragment, patterns of genetic structuring obtained by the analysis of this mitochondrial marker are largely comparable to those obtained through the analysis of polymorphic allozyme markers. The hierarchical design adopted in this study allowed us to estimate the relative amount of genetic variance at different spatial scales and showed that, for both the COI and allozyme data, the largest part of the total genetic variance is related to differences occurring among sites and among individuals. Conversely, structuring among North Adriatic estuaries do not seem to contribute significantly to the overall genetic variance of $H$. diversicolor. Earlier data suggested significant genetic differentiation among populations of $H$. diversicolor along the North Adriatic coast of Italy (Virgilio \& Abbiati 2004b). The present results show that the genetic structuring previously attributed to isolation among estuarine environments of the North Adriatic Sea (Virgilio \& Abbiati 2004b) is primarily related to a genetic fragmentation within estuaries. Small scale genetic structuring thus appears a major source of genetic variation in $H$. diversicolor. Eggs of $H$. diversicolor are fertilised and incubated in the maternal tubes and larvae start burrowing as soon as they emerge from the parental gallery. Short dispersal capabilities and local recruitment were hypothesised to promote genetic fragmentation (reviewed in Scaps 2002). Results from the present study support this model and suggest that, within estuaries, H. diversicolor does not form contiguous and freely mixing populations, but rather lives in fragmented populations that are isolated at small spatial scales.

Several population genetic studies of invertebrates (e.g. Johnson \& Black 1984, Watts et al. 1990, Casu et al. 2005) show substantial levels of genetic divergence at the smaller spatial scales. One explanation for these patterns is that individuals within sites are offspring of a small number of matings, as described by the sweepstake recruitment model (Avise 2000). Small scale genetic variability may also be related to genetic drift and bottlenecks occurring within populations (Avise 2000). Accordingly, local recruitment and limited dispersal may promote genetic drift within fragmented and isolated populations of Hediste diversicolor (Scaps 2002). Gillet \& Torresani (2003) in describing population dynamics and secondary production of $H$. diversicolor hypothesised that periodic mortality events followed by recruitment peaks promote temporal variations in densities of populations. This model is supported by the temporal variability observed in the local genetic patterns of $H$. diversicolor (Virgilio \& Abbiati 2006) suggesting that genetic drift due to fluctuations in densities of populations may be an important microevolutionary process affecting the genetic patterns of this species and that, within estuaries, populations of $H$. diversicolor are structured by chaotic genetic patchiness (Avise 2000). Furthermore, several 
Table 4. Hediste diversicolor. Spearman rank correlation coefficients $\left(r_{S}\right)$ showing lack of correlations between concentrations of $\mathrm{Cd}, \mathrm{Cu}, \mathrm{Pb}, \mathrm{Ni}$ and $\mathrm{Zn}$ (in estuarine sediments and $H$. diversicolor tissues) and estimators of genetic diversity ( $h=$ mtDNA haplotype diversity; $\pi=$ mtDNA nucleotide diversity, observed heterozygosities at allozyme loci ALD, FH, PGI, LDH and SDH) at 15 sampling

sites along the North Adriatic coast of Italy (see 'Materials and methods')

\begin{tabular}{|lrrrrr|}
\hline & $\mathrm{Cd}$ & $\mathrm{Cu}$ & $\mathrm{Pb}$ & $\mathrm{Ni}$ & $\mathrm{Zn}$ \\
\hline Sediments & & & & & \\
$h$ & 0.142 & -0.031 & -0.276 & -0.435 & 0.166 \\
$\pi$ & -0.257 & -0.257 & -0.048 & -0.348 & -0.247 \\
ALD $H_{\text {obs }}$ & 0.244 & 0.058 & -0.176 & -0.053 & 0.126 \\
FH $H_{\text {obs }}$ & 0.479 & 0.329 & -0.009 & -0.048 & 0.497 \\
LDH $H_{\text {obs }}$ & 0.241 & 0.026 & 0.227 & -0.314 & 0.275 \\
PGI $H_{\text {obs }}$ & -0.11 & 0.034 & 0.126 & -0.34 & -0.08 \\
SDH $H_{\text {obs }}$ & 0.28 & 0.125 & -0.006 & -0.039 & 0.317 \\
$\boldsymbol{H}$ diversicolor tissues & & & & & \\
$h$ & -0.327 & -0.356 & -0.164 & -0.488 & -0.025 \\
$\pi$ & -0.272 & -0.309 & -0.329 & -0.348 & -0.198 \\
ALD $H_{\text {obs }}$ & 0.032 & 0.381 & 0.277 & -0.05 & -0.206 \\
FH $H_{\text {obs }}$ & -0.103 & 0.219 & 0.286 & 0.055 & 0.188 \\
LDH $H_{\text {obs }}$ & -0.037 & -0.156 & 0.027 & -0.078 & 0.213 \\
PGI $H_{\text {obs }}$ & -0.36 & -0.063 & -0.05 & -0.205 & -0.342 \\
SDH $H_{\text {obs }}$ & -0.089 & -0.007 & 0.074 & -0.027 & 0.144 \\
\hline
\end{tabular}

Adriatic sites were generally low. Regardless of the lack of correlations between patterns of heavy metal contamination and genetic structure of $H$. diversicolor along the North Adriatic coast of Italy, we can not exclude that higher concentrations of heavy metals may promote appreciable genetic effects in field populations of this species. The present study shows that expectations from genotoxicological experiments performed under controlled laboratory conditions may be confounded by the complex interactions between ecological and microevolutionary processes occurring in the field. A deep knowledge of the genetic and life history traits of target species thus appears crucial to consider population genetics as a tool for monitoring the environmental impacts of contaminants. allozyme loci in this and previous studies (Virgilio \& Abbiati 2004b, 2006) show significant deviations from HWE proportions, as expected under sweepstake recruitment or genetic drift (Avise 2000).

Concentrations of heavy metals in sediments and tissues of Hediste diversicolor varied both within and among North Adriatic estuaries. Comparisons with ERL and ERM guideline values show that concentrations of $\mathrm{Cd}, \mathrm{Cu}, \mathrm{Pb}$ and $\mathrm{Zn}$ in sediments are moderately low at most of the investigated sites. Conversely, sediment concentrations of Ni were between ERL and ERM guidelines in 9 of the 15 sites, and above ERM at 3 sites. Regardless of expectations of biological effects, we did not observe correlations between concentrations of heavy metals and estimators of genetic diversity in $H$. diversicolor based on both mitochondrial and allozyme markers. Furthermore, frequencies of the ALD ${ }^{102 / 102}$ genotype were not correlated with $\mathrm{Cu}$ concentrations and hence did not support laboratory expectations about distributions of less tolerant ALD genotypes in the field (Virgilio et al. 2005). Previous studies showed that populations of $H$. diversicolor from heavily contaminated sites in the UK had heritable tolerance to heavy metals, suggesting the occurrence of adaptive responses promoted by heavy metal stress (Bryan \& Hummerstone 1971, Grant et al. 1989). However, concentrations of metals in polluted sites of the UK were up to 2 orders of magnitude higher than those observed in North Adriatic Sea sites. Genotypic shifts previously observed at ALD were promoted by laboratory exposures to acute $\mathrm{Cu}$ stress (Virgilio et al. 2005), while levels of $\mathrm{Cu}$ contamination in the North
Acknowledgements. We are grateful to F. Bertozzi, F. Costantini, G. Frangipane, S. Maci, D. Tagliapietra and T. Worsey for their invaluable support during sampling and laboratory activities. The SSCP analyses were performed at the Marine Biological Association of the UK, Plymouth (MBA) and, partially, at Royal Belgian Institute of Natural Sciences, Brussels (RBINS). Chemical analyses were kindly carried out by F. Conte at the ENEA Marine Environment Research Centre (La Spezia, Italy). We thank J. Bishop (MBA) and F. Pannacciulli (ENEA) for providing expertise and access to facilities and J. Preston (MBA) and P. Van Riel (RBINS) for uncomplaining tuition during SSCP analyses. We are grateful to V. Baravelli, R. Passaro and A. Pasteris for stimulating comments on earlier drafts of the manuscript. The manuscript has benefited from the valuable comments of 2 anonymous reviewers. This paper was written under the EU funded research contract EVK3-CT-200100048 (EUMAR) and has benefited from funding from the ABC Project (European Union) and Marco Polo Project (University of Bologna, Italy).

\section{LITERATURE CITED}

Abbiati M, Maltagliati F (1996) Allozyme evidence of genetic differentiation between populations of Hediste diversicolor (Polychaeta: Nereididae) from the western Mediterranean. J Mar Biol Assoc UK 76:637-647

Avise JC (2000) Phylogeography: the history and formation of species. Harvard University Press, Cambridge, MA

Belfiore NM, Anderson SL (2001) Effects of contaminants on genetic patterns in aquatic organisms: a review. Mutat Res 489:97-122

Belkhir K, Borsa P, Goudet J, Bonhomme F (1996) GENETIX, logiciel sous Windows ${ }^{\mathrm{TM}}$ pour la génétique des populations. Laboratoire Génome, Populations, Interactions, Université de Montpellier II, Montpellier

Benjamini Y, Hochberg Y (1995) Controlling the false discov- 
ery rate: a practical and powerful approach to multiple testing. J R Stat Soc 57:289-300

Bickham JW, Sandhu S, Hebert PDN, Chikhi L, Athwal R (2000) Effects of chemical contaminants on genetic diversity in natural populations: implications for biomonitoring and ecotoxicology. Mutat Res 463:33-51

Bilton DT, Paula J, Bishop JDD (2002) Dispersal, genetic differentiation and speciation in estuarine organisms. Estuar Coast Shelf Sci 55:937-952

Breton S, Dufresne F, Desrosiers G, Blier PU (2003) Population structure of two northern hemisphere polychaetes, Neanthes virens and Hediste diversicolor (Nereididae), with different life-history traits. Mar Biol 142:707-715

Bryan GW, Hummerstone LG (1971) Adaptation of the polychaete Nereis diversicolor to estuarine sediments containing high concentrations of heavy metals. J Mar Biol Assoc UK 51:845-863

Bryan GW, Langston WJ (1992) Bioavailability, accumulation and effects of heavy metals in sediments with special reference to United Kingdom estuaries. A review. Environ Pollut 76:89-131

Casu M, Maltagliati F, Cossu P, Lai T, Curini Galletti M, Castelli A, Commito JA (2005) Fine-grained spatial genetic structure in the bivalve Gemma gemma from Maine and Virginia (USA), as revealed by Inter-Simple Sequence Repeat markers. J Exp Mar Biol Ecol 325:46-54

Cavalli-Sforza LL, Edwards AWF (1967) Phylogenetic analysis: model and estimation procedures. Evolution 21:550-570

Clarke KR, Gorley RN (2001) PRIMER v5 Plymouth: user manual/tutorial. PRIMER-E, Plymouth

Clement M, Posada D, Crandall KA (2000) TCS: a computer program to estimate gene genealogies. Mol Ecol 9: $1657-1659$

Desroy N, Retière C, Thiébaut E (1998) Infaunal predation regulates benthic recruitment: an experimental study of the influence of the predator Nephtys hombergii (Savigny) on recruits of Nereis diversicolor (O.F. Müller). J Exp Mar Biol Ecol 228:257-272

De Wolf H, Blust R, Backeljau T (2004) The use of RAPD in ecotoxicology. Mutat Res 566:249-262

Diez G, Soto M, Canton L, Vaquero MC, Marigomez I (2000) Hediste (Nereis) diversicolor as bioindicator of metal and organic chemical bioavailability. Ecotoxicol Environ Restor 3:7-15

Excoffier L, Smouse PE, Quattro JM (1992) Analysis of molecular variance inferred from metric distances among DNA haplotypes: application to human mitochondrial DNA restriction data. Genetics 131:479-491

Gillet P, Torresani S (2003) Structure of the population and secondary production of Hediste diversicolor (O.F. Müller, 1776), (Polychaeta, Nereidae) in the Loire estuary, Atlantic Coast, France. Estuar Coast Shelf Sci 56:621-628

Grant A, Hateley JG, Jones NV (1989) Mapping the ecological impact of heavy metals on the estuarine polychaete Nereis diversicolor using inherited metal tolerance. Mar Pollut Bull 20:235-236

Hansen K, Kristensen E (1998) The impact of the polychaete Nereis diversicolor and enrichment with macroalgal (Chaetomorpha linum) detritus on benthic metabolism and nutrient dynamics in organic-poor and organic-rich sediment. J Exp Mar Biol Ecol 231:201-223

Johnson MS, Black R (1984) Pattern beneath the chaos: the effect of recruitment on genetic patchiness in an intertidal limpet. Evolution 38:1371-1383

Kumar S, Tamura K, Jakobsen IB, Nei M (2001) MEGA2: mol- ecular evolutionary genetics analysis software. Bioinformatics 17:1244-1245

Long ER, MacDonald DD, Smith SL, Calder FD (1995) Incidence of adverse biological effects within ranges of chemical concentrations in marine and estuarine sediments. Environ Manage 19:81-97

Long ER, Jay Field V, MacDonald DD (1998) Predicting toxicity in marine sediments with numerical sediment quality guidelines. Environ Toxicol Chem 17:714-727

Nei M (1978) Estimation of average heterozygosity and genetic distance from a small number of individuals. Genetics 89:583-590

Ozoh PTE (1994) The effect of salinity, temperature and time on the accumulation and depuration of copper in ragworm, Hediste diversicolor (O.F. Muller). Environ Monit Assess 29:155-166

Rohner M, Bastrop R, Jurss K (1997) Genetic differentiation in Hediste diversicolor (Polychaeta: Nereididae) for the North Sea and the Baltic Sea. Mar Biol 130:171-180

Scaps P (2002) A review of the biology, ecology and potential use of the common ragworm Hediste diversicolor (O.F. Müller) (Annelida: Polychaeta). Hydrobiologia 470:203-218

Schneider S, Roessli D, Excoffier L (2000) Arlequin, version 2.000: a software for population genetics data analysis. Genetics and Biometry Laboratory, University of Geneva

Schneppenheim R, MacDonald CM (1984) Genetic variation and population structure of krill (Euphausia superba) in the Atlantic sector of Antarctic waters and of the Antarctic peninsula. Polar Biol 3:19-28

Staton JL, Schizas NV, Chandler GT, Coull BC, Quattro JM (2001) Ecotoxicology and population genetics: the emergence of 'phylogeographic and evolutionary ecotoxicology'. Ecotoxicology 10:217-222

Thompson JD, Gibson TJ, Plewniak F, Jeanmougin F, Higgins DG (1997) The ClustalX windows interface: flexible strategies for multiple sequence alignment aided by quality analysis tools. Nucleic Acids Res 24:4876-4882

Virgilio M, Abbiati M (2004a) Allozyme genotypes and tolerance to copper stress in Hediste diversicolor (Polychaeta: Nereididae). Mar Pollut Bull 49:978-985

Virgilio M, Abbiati M (2004b) Habitat discontinuity and genetic structure in populations of the estuarine species Hediste diversicolor (Polychaeta: Nereididae). Estuar Coast Shelf Sci 61:361-367

Virgilio M, Abbiati M (2006) Temporal changes in the genetic structure of intertidal populations of Hediste diversicolor (Polychaeta: Nereididae). J Sea Res 56:53-58

Virgilio M, Baroncini N, Trombini C, Abbiati M (2003) Relationships between sediments and tissues contamination and allozymic patterns in Hediste diversicolor (Polychaeta: Nereididae) in the Pialassa lagoons (North Adriatic Sea). Oceanol Acta 26:85-92

Virgilio M, Maci S, Abbiati M (2005) Comparisons of genotype-tolerance responses in populations of Hediste diversicolor (Polychaeta: Nereididae) exposed to copper stress. Mar Biol 147:1305-1312

Watts RJ, Johnson MS, Black R (1990) Effects of recruitment on genetic patchiness in the urchin Echinometra mathaei in Western Australia. Mar Biol 105:145-151

Weir BS, Cockerham CC (1984) Estimating F-statistics for the analysis of population structure. Evolution 38: $1358-1370$

Winnepenninckx B, Backeljau T, De Wachter R (1993) Extraction of high molecular weight DNA from molluscs. Trends Genet 9:407 